\title{
Influence of light and photoperiodicity on pig prolificacy
}

\author{
R. Claus and U. Weiler \\ Universität Hohenheim, Institut für Tierhaltung und Tierzüchtung-470, P.O.B. 700562. \\ 7000 Stuttgart 70, West Germany
}

\begin{abstract}
Summary. In the wild pig mating activity is seasonal. The main breeding period is in late autumn but a second period may occur around April. It is known from other species that seasonal variations in breeding activity are mainly regulated by photoperiod.

In the domestic pig seasonal influences on prolificacy still exist: for example, AI boars not only show decreased steroid synthesis, sperm counts and libido in summer compared with the optima which occur in winter but also a biphasic pattern with a transient increase in spring. In cyclic sows ovarian function may be affected with anoestrus mainly in summer and occasionally in February/March. Additionally ovulation rate may be lower in summer and the duration of oestrus prolonged compared with that in late autumn and winter. In consequence the interval from weaning to oestrus is prolonged in summer and mating during this season leads to lower conception rates and slightly smaller litters. Light programmes which extend the daily light period to a constant $15-16 \mathrm{~h}$ seem to be ineffective in improving reproductive characteristics of the sow but stimulate the sucking frequency of piglets and increase survival of piglets with a low birthweight. Simulation, in summer, of the decreasing photoperiod (naturally occurring in autumn) stimulates the reproductive characteristics of Al boars, optimizing testicular steroid production, libido and semen composition. Similarly, a programme of decreasing light (20 min decrease/week) from May to August removed the seasonal increase (June-August) of the weaning-to-oestrus interval which was 5.7 days (compared with 23.6 days for the controls).

An interaction between photoperiod and puberty attainment seems to exist for male and female pigs. Further experiments with appropriate light programmes, however, are necessary to clarify this interaction.
\end{abstract}

\section{Photoperiod as an environmental factor controlling seasonal reproduction in mammals}

Seasonal reproduction is a well known phenomenon in animals living in the wild and is still obvious in some domesticated animals. It ensures that the offspring are born when chances of survival are at their optimum. The anticipated time of conception is controlled by the variation in the duration of daylength, as this is the only highly repeatable environmental factor available (Ortavant, Mauleon \& Thibault, 1964; Turek \& Campbell, 1979; Lincoln \& Short, 1980). Consequently, light programmes may be used to influence reproduction. Neither the light intensity nor the wavelength seem to be the crucial features for a light programme in mammals (Lincoln \& Short, 1980). In the sheep it has been shown that it is the change from long daily light periods to short periods which is the effective stimulus (Ducker, Thwaites \& Bowman, 1970a, b).

In the wild pig reproduction is clearly seasonal with a biphasic pattern. While the main breeding season is in late autumn, second one may occur around April so that the farrowing percentage of sows is highest in April with another increase around August. From July to September all the sows in the population are anoestrous (Mauget, 1982). Measurements of testicular steroids in seminal 
plasma of a wild boar routinely used for semen collection have revealed the highest concentrations in late autumn. In summer libido decreased, so that in August and September the boar has been shown to refuse to mount the dummy (Schopper, Gaus, Claus \& Bader, 1984).

In the domestic pig, sensitivity to photoperiodic stimuli does not seem to have disappeared and this paper considers the influence of photoperiod on various reproductive characteristics. In addition, the still limited attempts to improve prolificacy with light programmes are discussed.

\section{Light and reproduction of male pigs}

\section{Seasonal variations in reproductive characteristics of the mature boar}

A pronounced seasonal pattern of testicular steroid production has been shown by measuring $5 \alpha$-androst-16-en-3-one ( $5 \alpha$-androstenone; boar taint steroid) in adipose tissue of boars at weekly intervals. Maximum concentrations were found around November and were about 5-fold higher than at other periods of the year (Claus, 1979). Such measurements are useful to determine the endocrine status of the testes (Claus \& Alsing, 1976).

Seasonal differences in the total number of spermatozoa have been well established. A significant difference $(P<0.001)$ was found between ejaculates from September until February $\left(72 \times 10^{9}\right)$ and from March until August $\left(56 \times 10^{9}\right)$ (Peter, Frank, Mudra \& Ueckert, 1981). Higher numbers of spermatozoa per ejaculate in winter may be achieved by increased volumes (Podzo \& Varadin, 1983) or by higher sperm concentrations (Peter et al., 1981). Additionally, in summer an increase in the number of morphologically abnormal spermatozoa and spermatozoa with cytoplasmic droplets may occur (Cerovsky, 1978; Kopriva \& Pikhard, 1981; Louda, Smerha \& Bachtik, 1983). The viability of spermatozoa 24 or $48 \mathrm{~h}$ after extending the semen is higher in ejaculates obtained in winter $(70 \%$ and $55 \%$ respectively) than in summer $(65 \%$ and $44 \%$ respectively) (Antonyuk, ll'inskaya \& Bezlyundikov, 1982).

Andrological characteristics of the domestic boar may vary throughout the year in a biphasic manner as they do in wild boar. Jaussiaux (1964) has described changes in the number of spermatozoa per ejaculate with a maximum in November, a decrease in February followed by a moderate increase in April/May and a nadir in June. A biphasic pattern has also been found for the ejaculate volumes of boars used for AI (Schindler, 1980) and has been reported for the number of motile spermatozoa per ejaculate (Louda et al., 1983).

\section{Influence of light programmes on reproductive characteristics of the mature boar}

Only a few studies of light programmes with mature boars have been reported. Mazzari, du Mesnil du Buisson \& Ortavant (1968) changed the light conditions of boars from the natural photoperiod (duration was not given) to $10 \mathrm{~h}$ or $16 \mathrm{~h}$ light per day. Environmental temperature was kept constant at 15 or $35^{\circ} \mathrm{C}$. Boars subjected to short daylength had an increased total number of spermatozoa $\left(\times 10^{9}\right.$ ) compared with those exposed to long daylengths in both temperature groups $\left(15^{\circ} \mathrm{C}: 67.7 \pm 2.8\right.$ (s.d.) vs $47.8 \pm 2.6 ; 35^{\circ} \mathrm{C}: 59.9 \pm 2.5$ vs $\left.46.9 \pm 2.9\right)$. It was concluded that photoperiod changes sperm production by influencing the hypothalamo-pituitary status, whereas high temperature has a direct destructive effect on the germ cells (Mazzari et al., 1968).

In experiments with 8 boars which were routinely used for $\mathrm{Al}, 4$ (daylight boars) were subjected to continuous changes of the natural photoperiod (longest day, $17 \mathrm{~h}$ light per day, in June; shortest day, $8 \mathrm{~h}$ light per day, in December). The other 4 (light programme) boars were kept in a dark building with a light programme which simulated the changes of the natural photoperiod with a

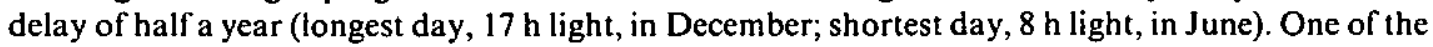
two ejaculates collected weekly was evaluated. Before ejaculation the reaction time was measured as a criterion of libido and blood samples were taken weekly from the ear vein during mounting of 

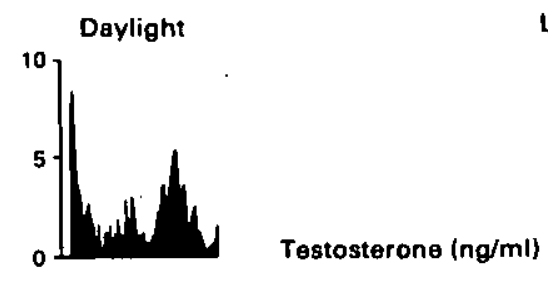

Light programme
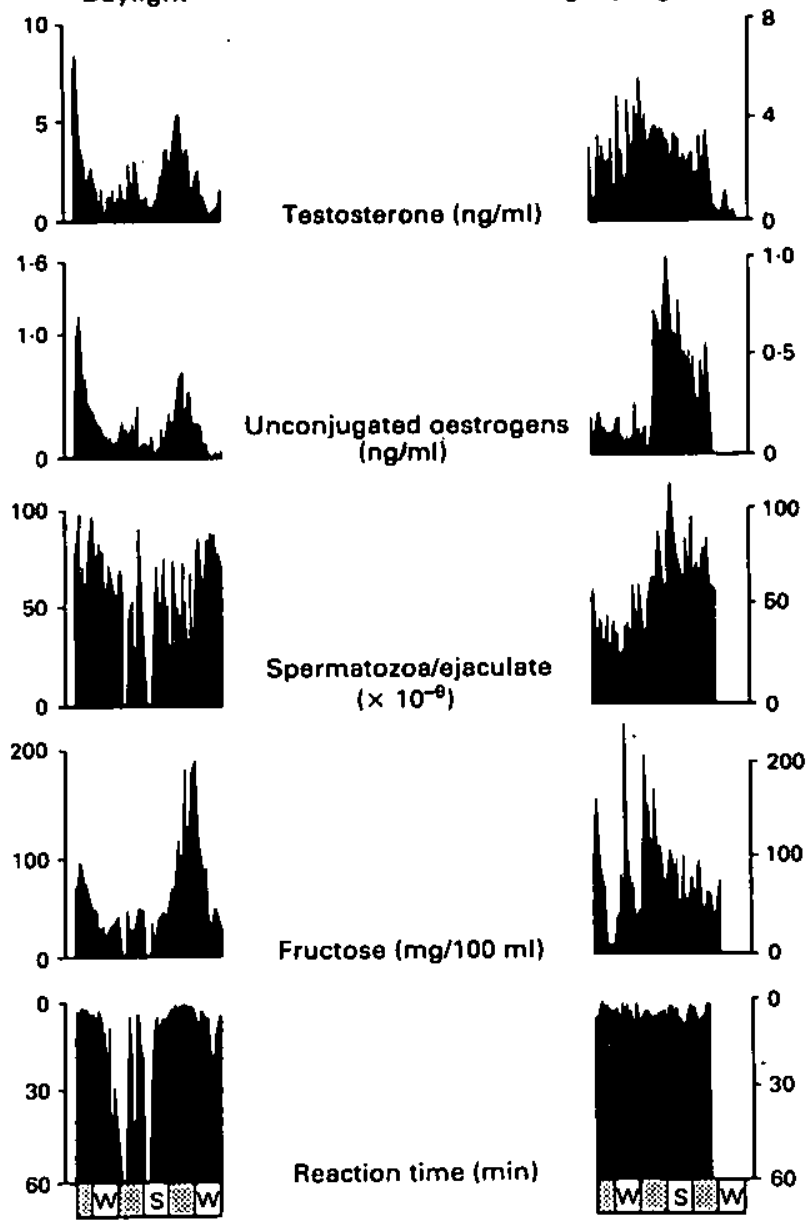

Fig. 1. Seasonal variations of steroid concentrations in blood plasma and several andrological characteristics of individual boars as influenced by the natural photoperiod (daylight) or a light-reversal programme (light programme). (After Claus et al., 1985a, b.)

the dummy. Annual profiles of andrological characteristics (Claus, Schopper \& Wagner, 1983; Claus, Schopper, Wagner \& Weiler, 1985a; Claus, Weiler \& Wagner, 1985b) of individual boars from both light regimens are shown in Fig. 1. In the daylight boars, the optima occurred in autumn and winter and an additional slight improvement was noted in spring. Thus in these boars the characteristics studied followed the usual biphasic pattern.

In the light-programme boars (Fig. 1) all characteristics were optimal in summer. Unconjugated oestrogens and spermatozoa/ejaculate apparently reacted with some delay and optimal values were found during July-September. An improvement in summer was also obvious when the mean values of several characteristics were compared for the 4 boars from both groups in July-September (Table 1).

Sperm production was expressed as 'spermatozoa/mounting attempt' to correct for elevated sperm counts in the ejaculates after refusals to mount. Additionally, to correct for differences in the overall level of spermatogenesis the figures are given as percentage of the initial period. This criterion is shown for the daylight boars and the light-programme boars according to the meteorological seasons in Fig. 2 and points to the stimulating effect of a decreasing natural or artificial photoperiod. 
Table 1. Mean values of reproductive characteristics during the period from July to September for 'daylight boars' and 'light programme boars' (from Claus et al., 1984, 1985a,b)

\begin{tabular}{lccc}
\hline Measurement & Daylight boars & $\begin{array}{c}\text { Light programme } \\
\text { boars }\end{array}$ & Significances \\
\hline $\begin{array}{l}\text { Testosterone } \\
\text { (ng/ml blood plasma) }\end{array}$ & 1.92 & 2.82 & $P<0.001$ \\
$\begin{array}{c}\text { Unconjugated oestrogens } \\
\text { (ng/mi blood plasma) }\end{array}$ & 0.18 & 0.35 & $P<0.001$ \\
$\begin{array}{l}\text { Fructose (mg/l00 ml } \\
\text { seminal plasma) }\end{array}$ & 44.9 & 86.2 & $P<0.001$ \\
$\begin{array}{c}\text { Reaction time } \\
(\text { min) }\end{array}$ & 11.8 & 5.1 & $P<0.01$ \\
\hline
\end{tabular}
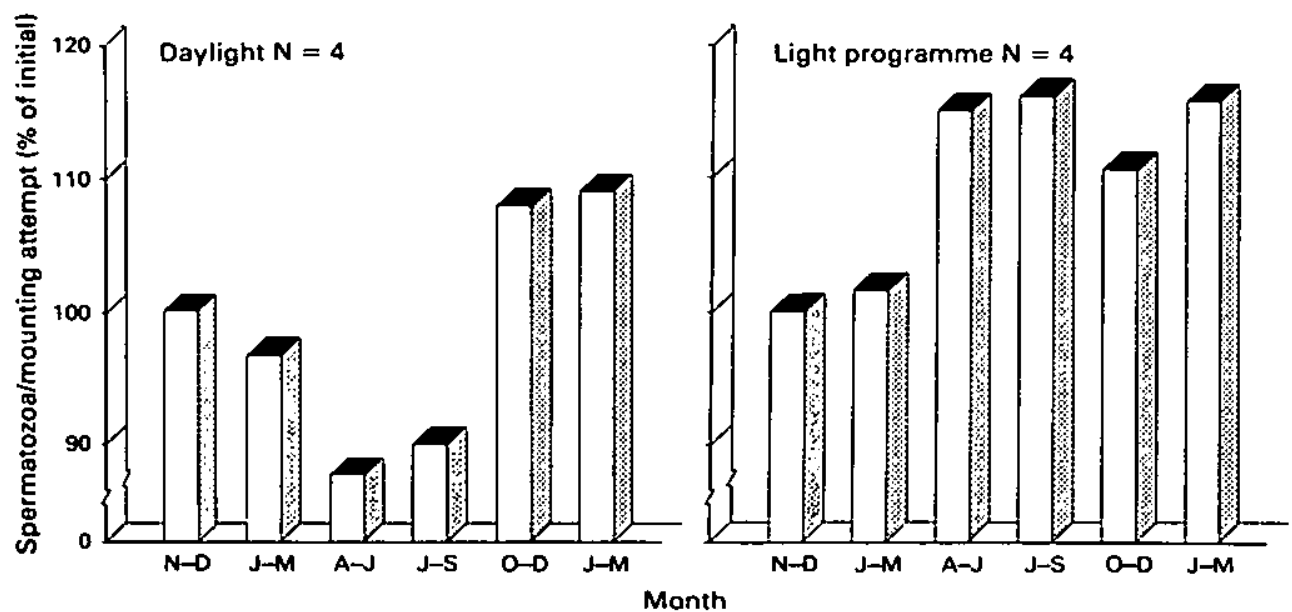

Fig. 2. Influence of the natural photoperiod (daylight) or a light-reversal programme (light programme) on spermatozoa/mounting attempt (see text) of Al boars. (After Claus et al., 1985b.)

The same programme was meanwhile applied in a large German AI station to half the boars. So far (U. Weiler, unpublished observations) the results show that from October to December the daylight boars $(\mathrm{N}=54)$ were significantly better than the light-programme boars, with respect to libido, ejaculate volume, spermatozoa per ejaculate and the number of doses obtained per ejaculate. Light-programme boars $(\mathrm{N}=59)$, with a variable degree of significance for each month, had improved values for these characteristics from June to September, thus confirming the results of the pilot study.

\section{Influence of light on pubertal development of male pigs}

Puberty in the boar becomes obvious at about 3 months of age when Leydig cells differentiate (Colenbrander, Frankenhuis \& Wensing, 1982) and testicular steroid synthesis starts to increase (Booth, 1975; Claus \& Hoffmann, 1980; Alirich, Christensen, Ford \& Zimmermann, 1982). Spermatogenesis, however, is not completed before an age of 4-5 months (Schilling, 1968). 
According to the experiments on the influence of light on mature boars, it may be assumed that pubertal development is stimulated by decreasing (stimulating) photoperiod and is delayed by increasing photoperiod. Based on this hypothesis the development of puberty was evaluated by the determination of testicular steroids in two consecutive groups of growing boars (half-sibs) (R. Claus, unpublished observations). The first group $(\mathrm{N}=20)$ was raised during the maximum increase of photoperiod starting at an age of 13 weeks on $10 \mathrm{March}$; the second group $(\mathrm{N}=20)$ was raised during the maximum decrease of photoperiod (13 weeks; 1 September).

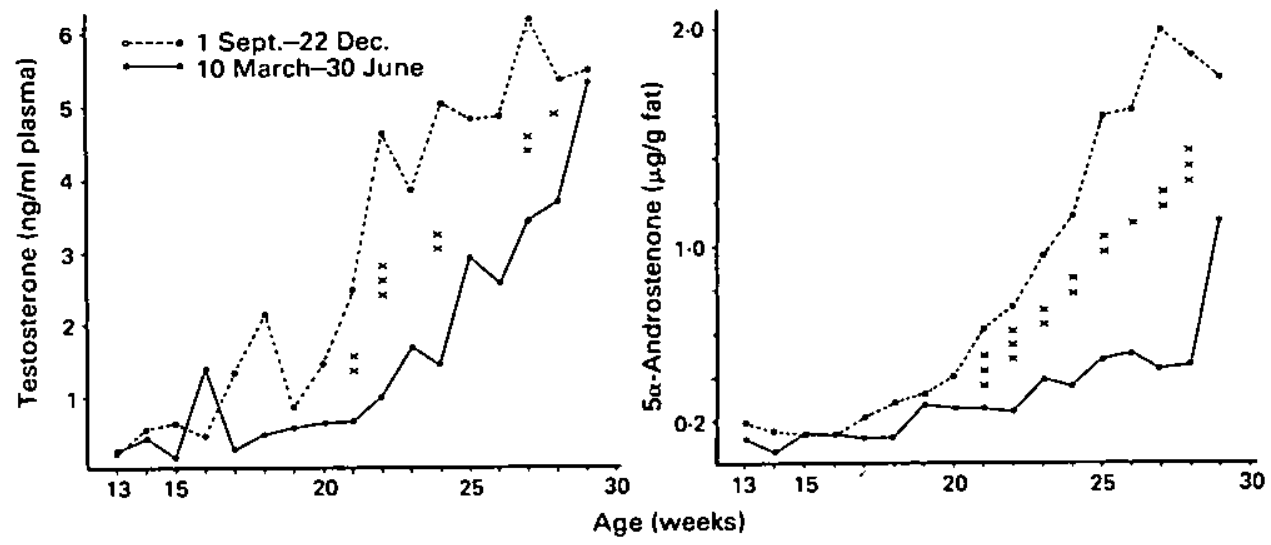

Fig. 3. Testicular steroids in male pigs raised during increasing (solid line, $\rightarrow-\rightarrow$ ) or decreasing (broken line, --) photoperiod. * $P<0.05$; $* * P<0.01$; ${ }^{* * *} P<0.001$. (R. Claus, unpublished observations.)

Testosterone concentrations in blood plasma, taken at weekly intervals from the ear vein of 5 pigs from each group, increased more rapidly in the boars raised under decreasing daylength than in those raised in increasing daylength (Fig. 3). The differences were significant at 16, 21, 23, 24, 27 and 28 weeks of age. Similarly, the concentrations of $5 \alpha$-androstenone in adipose tissue were significantly higher throughout the period of 21-28 weeks of age for the boars raised under decreasing photoperiod. In addition blood and adipose tissue from the other 15 animals in each group were collected at a weight of $100 \mathrm{~kg}$ (about 24 weeks of age). Testosterone concentrations were more than 3-fold higher in the boars exposed to decreasing daylength $(P<0.001)$ and $5 a$-androstenone concentrations in adipose tissue were also significantly $(P<0.001)$ higher for the same group.

The results with controlled light conditions do not provide a definite conciusion. Pubertal development of boars kept with constant light of 8 or $16 \mathrm{~h}$ per day showed no differences for testicular and epididymal weight, epididymal sperm numbers and serum LH concentrations. However, testicular sperm numbers and testosterone concentrations in blood plasma tended to be higher (not significantly) in the boars exposed to $16 \mathrm{~h}$ light (Minton, Fent \& Wettemann, 1980). The effects of supplemental light ( $15 \mathrm{~h}$ light/day) have been compared to the natural photoperiod during various seasons of the year (Mahone, Berger, Clegg \& Singleton, 1979; Berger, Mahone, Svoboda, Metz \& Clegg, 1980; Greenberg \& Mahone, 1981; Hoagland \& Diekman, 1982). No definite influence on the onset of spermatogenesis (e.g. appearance of first spermatozoa in urine or preputial fiuid) and later differences in semen composition were obvious. In some studies libido scores tended to be improved for the boars with supplemental light.

As a comparison of pubertal development under decreasing or increasing light programmes has not yet been undertaken, light-puberty interactions in the boar need further investigation. 


\section{Light and reproduction of the female pig}

Annual differences of reproductive phenomena which contribute to prolificacy in the sow have attracted considerable interest. Results from many countries where various reproductive traits have been examined confirm the existence of a period of lowered fertility in summer (Fig. 4). Seasonal changes of traits influencing farrowing interval and litter size are considered further.

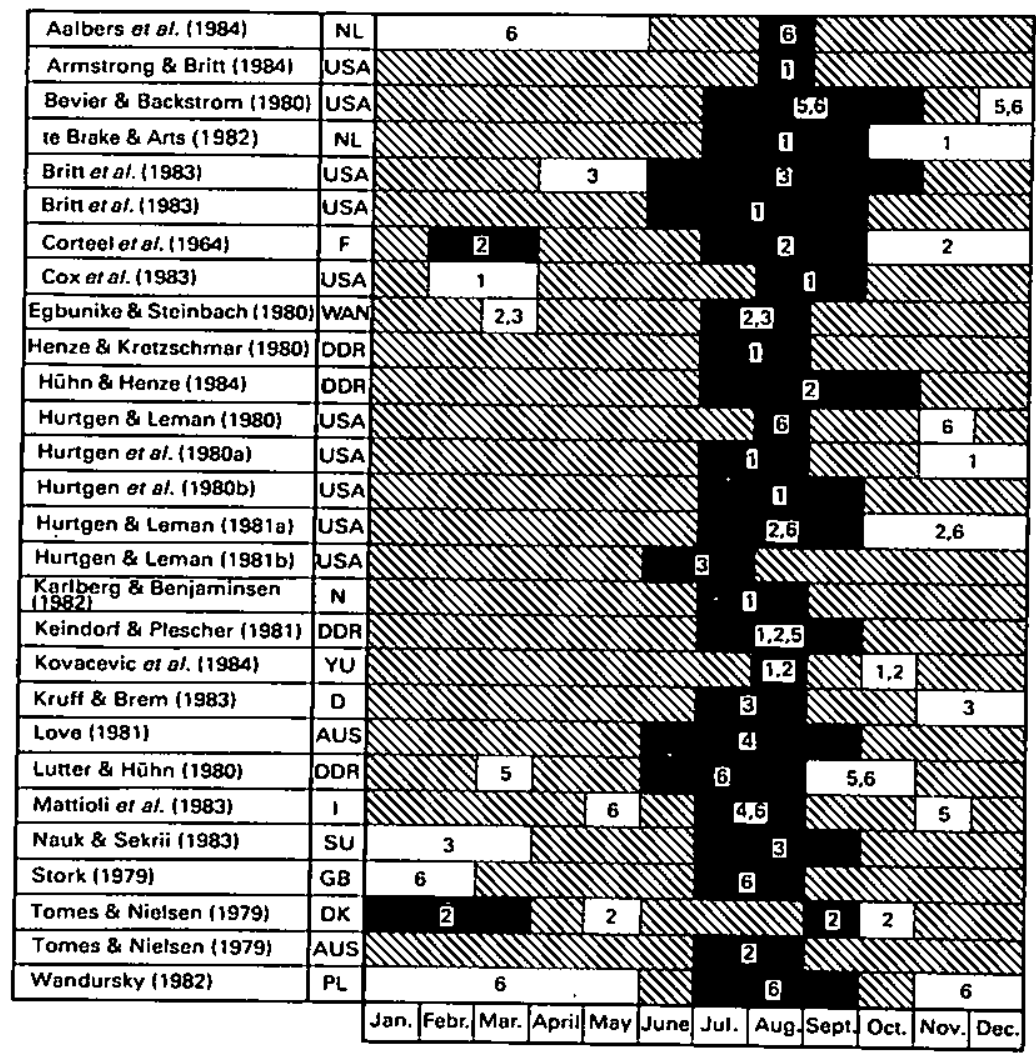

Fig. 4. Investigations on seasonal reproductive problems in the sow. Black bars indicate periods with lowered reproductive measures, white bars of improved measures compared with the rest of the year (southern hemisphere adapted to northern hemisphere). 1 = Weaning-to-oestrus interval; 2 = conception rate; $3=$ weaning-to-conception interval; $4=$ embryonic loss; $5=$ litter size, depending on the month of conception; $6=$ farrowing rate, depending on the month of conception.

\section{Seasonal variations in reproductive characteristics of the sow}

Weaning-to-oestrus interval. After weaning the piglets, a sow should return to oestrus within 7 days. This weaning-to-oestrus interval, however, is generally prolonged during summer and tends to be improved during October to January (Corteel, Signoret \& du Mesnil du Buisson, 1964; Hurtgen \& Leman, 1981a, b; Keindorf \& Plescher, 1981; te Brake \& Arts, 1982; Britt, Szarek \& Levis, 1983; Noguera, Felgines \& Legault, 1983). The use of cooling systems has not yet prevented the increased interval in summer (Hurtgen, Leman \& Crabo, 1980b; Britt et al., 1983; Cox, Britt, Armstrong \& Alhusen, 1983). 
The percentage of sows returning to oestrus within 7 days was only $68 \cdot 6 \%$ during July to September, compared with $82.0 \%$ during the rest of the year (Hurtgen et al., 1980a); a similar result $(50.5$ and $72 \%$ ) has been reported by te Brake \& Arts (1982). Average intervals of 23.6 days in summer and 10.8 days in autumn have been reported by Claus, Schelkle \& Weiler (1984) and of 28 and 17 days by Aumaitre, Dagorn, Legault \& le Denmat (1976). Additionally, the chance of an abnormally prolonged interval until first oestrus (more than 30 or even 45 days) is two-fold greater in summer than at other times of the year (Corteel et al., 1964; Hurtgen et al., 1980a) and may lead to replacement of multiparous sows by gilts. In primiparous sows, however, the interval is even more prolonged in summer (Hurtgen et al., 1980a; Britt et al., 1983).

Progesterone concentrations in the blood plasma are constantly low until the first observed oestrus (Armstrong \& Britt, 1984; Claus et al., 1984; Kovacevic et al., 1984), and so silent oestrus seems to be the exception.

Increased intervals to oestrus seem to occur when weaning coincides with a period of lowered ovarian activity. In a slaughterhouse study Hurtgen \& Leman (1978) found more than $40 \%$ of sows with inactive ovaries in August (Fig. 5). Ovarian inactivity is also obvious in a current study in which the annual progesterone profiles of cyclic sows are being obtained ( $R$. Claus, unpublished observations). Figure 6 shows the pattern from one animal which spontaneously ceased cycling

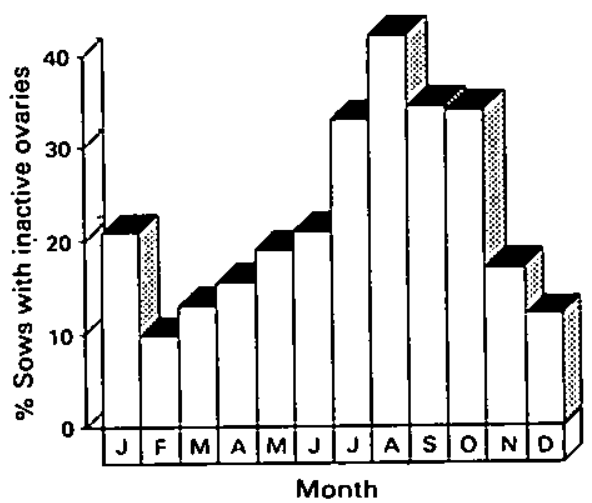

Fig. 5. Seasonal distribution of the percentage of sows with inactive ovaries as found in a slaughterhouse study. (After Hurtgen \& Leman, 1978.)

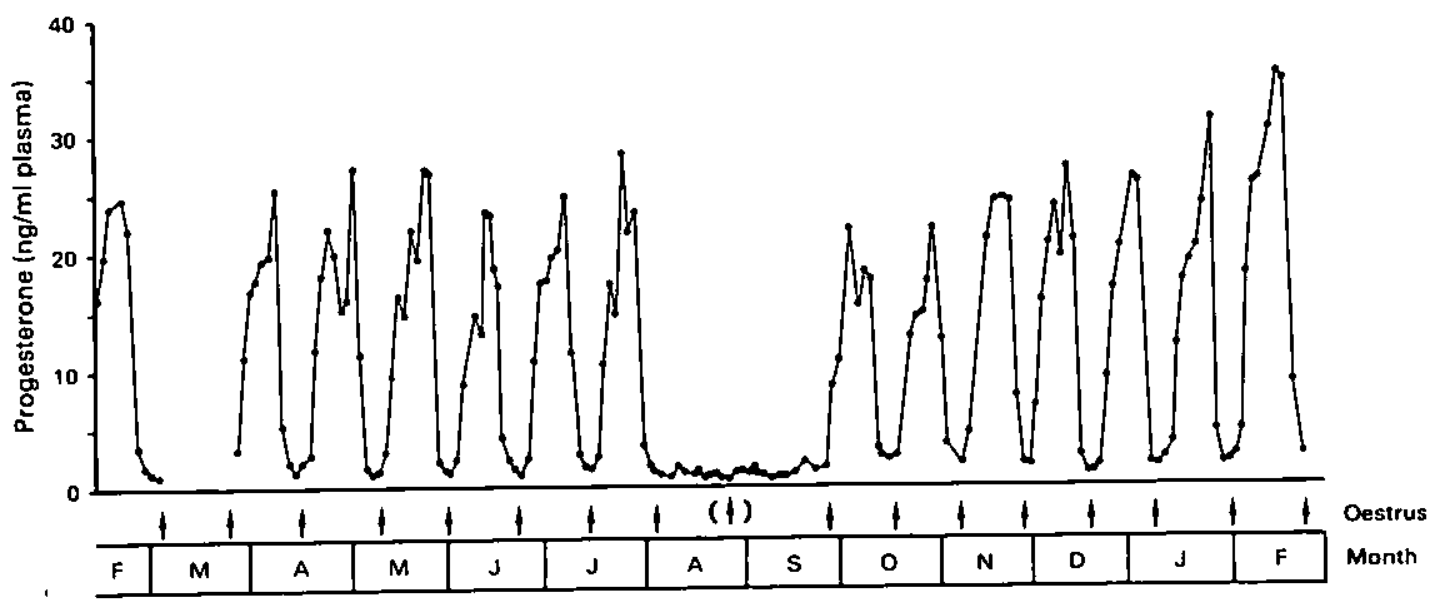

Fig. 6. Annual profile of progesterone concentrations in a cyclic sow. Cathcter failure in March; weak symptoms of oestrus at the end of August during the acyclic period. (R. Claus, unpublished observations.) 
from the beginning of August until the end of September and then resumed cyclic activity. Anoestrus was obvious in this study in the period of July to October in 6 out of 15 sows and in 3 sows also during February and March. Anoestrus did not occur in December to January and April to June.

Conception and farrowing rate. Farrowing rate is generally suboptimal when insemination or mating take place between July and September (Stork, 1979; Hurtgen \& Leman, 1980; Wandursky, 1982; Aalbers, Johnson, Rademaker \& Grooten, 1984). This annual decrease may arise as early as May or June (Lutter \& Hühn, 1980; Bevier \& Backstrom, 1980; Hurtgen \& Leman, 1981b) and extend to September or October and is not prevented by cooling methods (Hurtgen \& Leman, 198 la). Farrowing rates above the average were found when insemination took place between late autumn and early spring (Stork, 1979; Hurtgen et al., 1980a; Hurtgen \& Leman, 1981a; Wandursky, 1982; Aalbers et al., 1984). The main explanation is that conception rate is decreased in summer and tends to be elevated in autumn and winter (Keindorf \& Plescher, 1981; Britt et al., 1983; Dobao, Rodriganez \& Silio, 1983; Mattioli, Taschini, Galeati \& Seren, 1983). The percentage of sows not conceiving in summer varies considerably and may be as high as $35 \cdot 5 \%$ compared with $23.5 \%$ in winter (Dobao et al., 1983) and $56 \%$ for gilts in summer (Kovacevic et al., 1984). The biphasic pattern of conception rate reported by Corteel et al. (1964) is shown in Fig. 7.

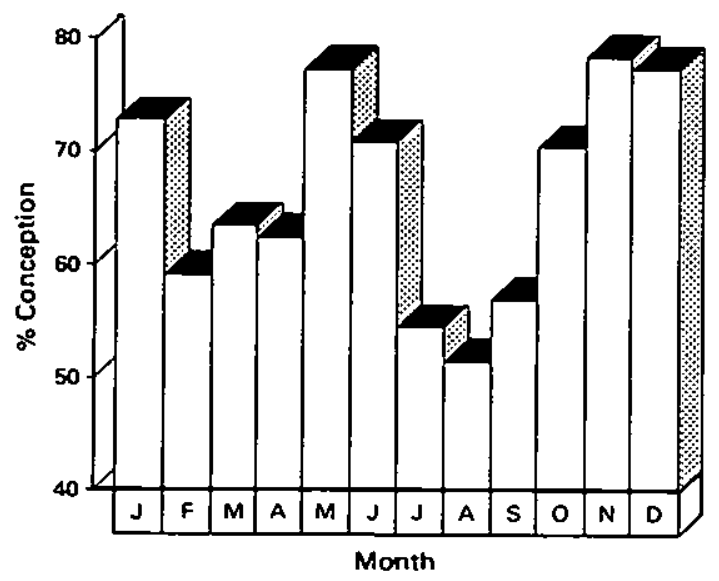

Fig. 7. Annual biphasic pattern of the conception rate. (After Corteel et al., 1964.)

An explanation of the annual differences in conception rate may be the problem of timing of $\mathrm{Al}$ or mating during the oestrous period. The time of ovulation within the oestrous period varies considerably (Foxcroft \& van de Wiel, 1982) and it is known that during summer the duration of oestrus is prolonged compared with autumn/winter (Signoret, 1967; Nauk \& Sekrii, 1983).

In addition, embryonic loss may cause a reduced farrowing rate (Stork, 1979; Mattioli et al., 1983): the highest incidence of abortions occurs in September/October mainly in sows mated between June and September. From all sows that were successfully inseminated during the period June to August (oestrone sulphate determination at Day 25), 25-30\% did not farrow, compared with only 4 and $6 \%$ of sows successfully inseminated in May and November respectively (Mattioli et al., 1983).

Litter size. Litter size is generally increased after mating in autumn and winter compared with summer (Tomes \& Nieisen, 1979; Keindorf \& Plescher, 1981; Bevier \& Backstrom, 1981; Dobao et al., 1983; Mattioli et al., 1983; Noguera et al., 1983; Aalbers et al., 1984). Litter size from matings in summer is usually at least 1 piglet less than that from autumn and winter matings (Bevier \& Backstrom, 1981; Mattioli et al., 1983). Increased litter size may also result from mating in 


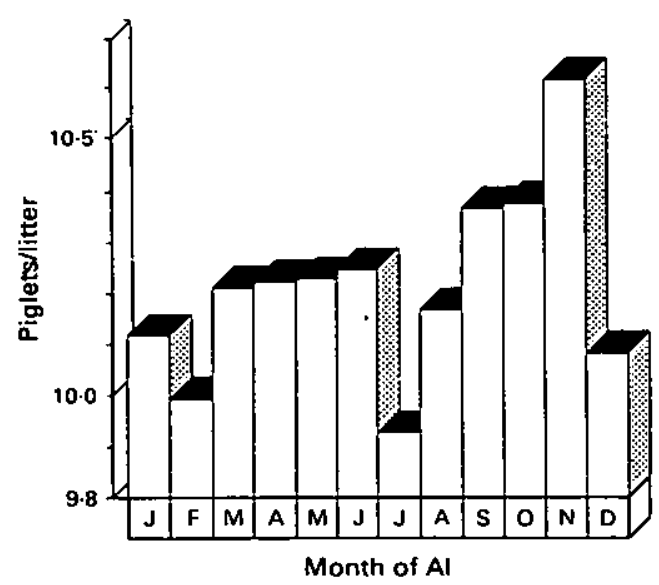

Fig. 8. Annual biphasic pattern of the litter size, depending on the month of AI. (After Mezger, 1984.)

April-May (Bevier \& Backstrom, 1981) and this fits with the biphasic pattern obtained by analysis of 9000 litters as shown in Fig. 8 (Mezger, 1984).

In mature sows, litter size seems to be determined mainly by uterine capacity which limits the number of embryos (Dziuk, 1977). In summer, however, reduced ovulation rate may also limit the litter size. Counting the corpora lutea of sows slaughtered 30 days after mating has shown that the ovulation rate appears to be at a maximum in autumn $(N=17)$ and at a minimum $(N=15)$ from the end of winter to spring (Martinat-Botte, Dando, Gautier \& Terqui, 1981); figures were not given for May-August because of the limited number of sows slaughtered. A tendency for increasing progesterone concentrations during consecutive luteal phases from summer to winter is obvious for the sow shown in Fig. 6. In the same study, statistical evaluation of 11 luteal phases for each month revealed that progesterone concentrations were significantly $(P<0.001)$ lower in August than in November, December and January (R. Claus, unpublished observations).

Progesterone concentrations in early pregnancy (Days 10-60 after AI) are significantly lower in August-September $(21.5 \mathrm{ng}$ progesterone/ml plasma) than in all other periods $(32.4-40.3 \mathrm{ng} / \mathrm{ml})$ (Bielanski \& Kremer, 1983). No differences, however, were found in the maximum progesterone concentrations during the luteal phase of gilts investigated in June-September or February-March (Perotti, Enne, Meggiolaro \& Delrio, 1979).

\section{Influence of light patterns on reproductive characteristics of the sow}

Constant photoperiod. Several experiments were designed to study the effects of supplemental light (daily light period artificially extended to $16 \mathrm{~h}$ ) compared with the natural photoperiod or a constant 8-h light per day on reproductive characteristics of the sow. The light regimen was changed at the end of pregnancy and was kept constant thereafter. No effect was found for the weaning-to-oestrus interval, conception rate, farrowing rate, or litter size (Greenberg \& Mahone, 1982; Mabry, Cunningham, Kraeling \& Rampacek, 1982; Mabry, Coffey \& Seerly, 1983). A late change from natural photoperiod (1 day after weaning) to $24 \mathrm{~h}$ dark or $24 \mathrm{~h}$ light or $12 \mathrm{~h}$ dark/12 h light per day did not influence these values (Perera, Hacker \& King, 1980; Perera \& Hacker, 1984). Long periods of light per day, however, prolonged manifestations of behavioural oestrus (Perera \& Hacker, 1984) similar to the natural photoperiod in summer.

Extending the photoperiod $(16 \mathrm{~h} v s \mathrm{~h})$ caused an increase of milk yield of nursing sows by 20-24\% (Mabry et al., 1982, 1983), so that the survival rate of the piglets born with low birth weights was improved (Mabry et al., 1982, 1983; Stevenson, Pollman, Davis \& Murphy, 1983). This 
is explained by an increased suckling frequency of the piglets (Mabry et al., 1983), which in turn both increased their nutrient supply and stimulated milk production.

Decreasing photoperiod. A decreasing light programme simulating the natural decrease of daylength in autumn was applied during summer in a piggery with 80 sows to improve the weaning-to-oestrus interval (Claus et al., 1984). At this farm the interval had been recorded in the year preceding the use of this light regimen and was found to increase to an average of 31.6 days in August (Fig. 9a). The programme started in May (15 h $20 \mathrm{~min}$ light) about 1 month before the expected seasonal increase of the weaning-to-oestrus interval. The daily light period was weekly diminished by $20 \mathrm{~min}$ until the end of August. After this period the sows returned from $10 \mathrm{~h}$ artificial to $13.5 \mathrm{~h}$ natural light, followed by the seasonal decrease of natural daylength. As shown in Fig. 9(b) the light programme markedly decreased the interval to an average of 5.7 days in June-August (28 sows weaned), compared with 23.6 days in the same period of the preceding year.

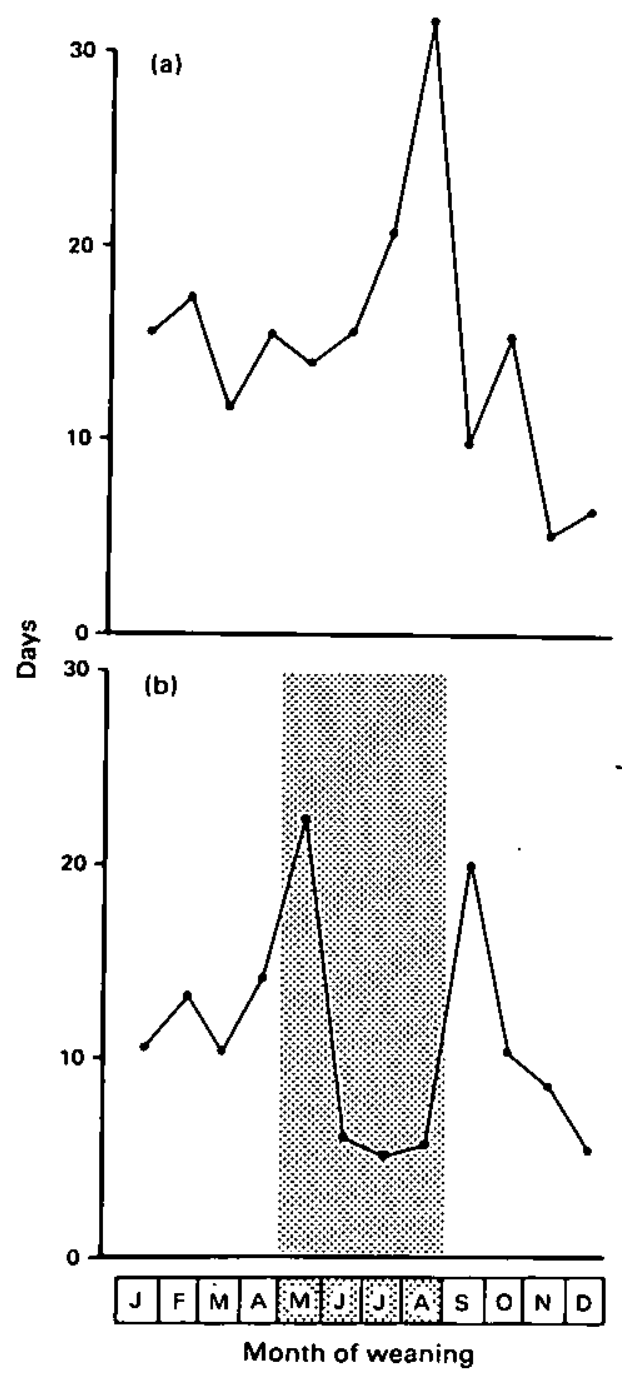

Fig. 9. Annual pattern of the weaning-to-oestrus interval as influenced by the natural photoperiod (a) or a decreasing-light programme (shaded area, b). (From Claus et al., 1984.) 
The return to the natural photoperiod at the end of August (sudden increase of photoperiod) resulted in a transient increase of the interval in September, which fell again as natural daylight decreased. The average monthly temperature in July and August was higher in the experimental year $\left(20 \cdot 1^{\circ} \mathrm{C}\right)$ than in the previous year $\left(18 \cdot 2^{\circ} \mathrm{C}\right)$.

\section{Light and puberty in the gilt}

Conflicting results have been obtained from studies on the effects of season on the attainment of puberty in the gilt (see review by Hughes, 1982). A delayed puberty in summer has been reported (Christenson, 1981), and a biphasic annual profile was obvious for the percentages of gilts showing first oestrus (Willecke, Metges \& Oster, 1984) and reaching puberty by 8 months of age (Maksimovic, 1983).

The influence of light programmes (constant duration of light/day) has also been reviewed (Hughes, 1982) and the conflicting nature of the results shown. Recent experiments with comparable light regimens have contributed to the conflict by confirming the suggested positive effect of long days (Diekman \& Hoagland, 1983) or finding a contradictory or no effect (Wise, Jones, Allrich \& Zimmermann, 1980; Christenson, 1981). The only light-decreasing regimen (Wright, English \& Robertson, 1984) was applied for 1 month only and did not allow conclusions to be drawn.

\section{References}

Aalbers, J.G., Johnson, L.A., Rademaker, J.M.H. \& Grooten, H.J.G. (1984) Use of boar spermatozoa for AI: fertility and morphology of semen diluted in bits and use for insemination within 24 hours or 25 to 48 hours after collection. Proc. $10 \mathrm{~h} \mathrm{lnt}$. Congr. Anim. Reprod. \& A.I., Urbana Vol. II, 180-182.

Altrich, R.D., Christenson, R.K., Ford J.J. \& Zimmermann, D.R. (1982) Pubertal development of the boar: testosterone, estradiol- $17 \beta$, cortisol, and LH concentrations before and after castration at various ages. J. Anim. Sci. 55, 1139-1146.

Antonyuk, V.S., ll'inskaya, T.P. \& Bezlyudnikov, L.G. (1982) The effects of season on semen quality of boars at large intensive farms. Nauch. Osnovy Razvitiva Zhivolnovodstva V BSSR 11, 28-30.

Armstrong, J.D. \& Britt, J.H. (1984) Eflect of energy restriction during lactation on reproductive performance, energy metabolites and endocrine changes in primiparous sows. Proc. IOth Int. Congr. Anim. Reprod.\& A.I., Urbana, Vol. II, I57-159.

Aumaitre, A., Dagorn, J., Legault, C. \& le Denmat, M. (1976) Influence of farm management and breed type on sow's conception-weaning interval and productivity in France. Livestock Prod. Sci. 3, 75-83.

Berger, T., Mahone, J.P., Svoboda, G.S., Metz, K.W. \& Clegg, E.D. (1980) Sexual maturation of boars and growth of swine exposed to extended photoperiod during decreasing natural photoperiod. J. Anim. Sci. 51, 672-678.

Bevier, G.W. \& Backstrom, L. (1980) Seasonal infertility pattern during 1978 in 22 swine herds in lowa and Nebraska, USA. Proc. 6th Int. Pig Vet. Soc., Copenhagen, p. 321, Abstr.
Bielanski, A. \& Kremer, M. (1983) Seasonal changes in plasma progesterone level in pregnant sows. Proc. 34th Ann. Meeting Eur. Assoc. Anim. Prod., Madrid, Vol. Il, 768-769.

Booth, W.D. (1975) Changes with age in the occurrence of $\mathrm{C} 19$ steroids in testis and submaxillary gland of the boar. J. Reprod. Fers. 42, 459-472.

Britt, J.H., Szarek, V.E. \& Levis, D.G. (1983) Characterization of summer infertility of sows in large confinement units. Theriogenology 20, 133-140.

Cerovsky, J. (1978) Morphological changes of the spermatozoa of breeding boars in the summer period. Sb. Esl. Akad. Zeméd. Vèd, E 23, 715-723.

Christenson, R.K. (\$981) Influence of confinement and season of the year on puberty and estrous activity of gilts. J. Anim. Sci. 52, 821-830.

Claus, R. (1979) Pheromone bei Säugetieren unter besonderer Berücksichtigung des Ebergeruchsstoffes und seiner Beziehung zu anderen Hodensteroiden. Fortschr. Tierphys. Tierern. Suppl. 10, Parey, Hamburg.

Claus, R. \& Alsing, W. (1976) EinfluB von Choriongonadotropin, Haltungsänderung und sexueller Stimulierung auf die Konzentrationen von Testosteron im Plasma sowie des Ebergeruchsstoffes im Plasma und Fett eines Ebers. Berl. Münch. tierärzll. Wschr. 89, 354-358.

Claus, R. \& Hofimann, B. (1980) Oestrogens, compared to other steroids of testicular origin, in blood plasma of boars. Acta endocr. Copenh. 94, 404-411.

Claus, R., Schopper, D. \& Wagner, H.G. (1983) Seasonal effect on steroids in blood plasma and seminal plasma of boars. J. Steroid Biochem. 19, 725-729. 
Claus, R., Schelkle, G. \& Weiler, U. (1984) Erste Versuche zur Verbesserung der Fruchtbarkeitslage von Sauen im Sommer durch ein Lichtprogramm. Zuchthygiene 19, 49-56.

Claus, R., Schopper, D., Wagner, H.-G. \& Weiler, U. (1985a) Photoperiodic influences on reproduction of domestic boars: I. Light influences on testicular steroids in peripheral blood plasma and seminal plasma. Zentbl. VetMed. A 32, 86-98.

Claus, R., Weiler, U. \& Wagner, H.-G. (1985b) Photoperiodic influences on reproduction of domestic boars: II. Light influences on semen characteristic and libido. Zenibl. VetMed. A 32, 99-109.

Colenbrander, B., Frankenhuis, M.T. \& Wensing, C.J.G. (1982) Male sexual development. In Control of Pig Reproduction, pp. 3-24. Eds D. J. A. Cole \& G. R. Foxcroft, Butterworth Scientific. London.

Corteel, J.M., Signoret, J.P. \& du Mesnil du Buisson F. (1964) Variations saisonnieres de la reproduction de la truie et facteurs favorisant l'anoestrus temporale. Proc. Sth Int. Congr. Anim. Reprod. \& Al, Trento, Vol. III, 536-540.

Cox, N.M., Britt, J.H., Armstrong, W.D. \& Alhusen, H.D. (1983) Effect of feeding fat and altering weaning schedule on rebreeding in primiparous sows. J. Anim. Sci. 56, 21-29.

Diekman, M.A. \& Hoagland, T.A. (1983) Influence of supplemental lighting during periods of increasing or decreasing daylength on the onset of puberty in gilts. J. Anim. Sci. 57, 1235-1242.

Dobao, M.T., Rodriganez, J. \& Silio, L. (1983) Seasonal influences on fecundity and litter performance characteristics in Iberian pig. Livestock Prod. Sci. 10, $601-610$.

Ducker, M.J., Thwaites, C.J. \& Bowman, J.C. (1970a) Photoperiodism in the ewe. I. The effect of long supplemented daylength on the breeding activity of pregnant and nonpregnant Teeswater-Clun ewes. Anim. Prod. 12, 107-113.

Ducker, M.J., Thwaites, C.J. \& Bowman, J.C. (1970b) Photoperiodism in ewe. 2. The effect of various patterns of decreasing daylength on the onset of oestrus in clun forest ewes. Anim. Prod. 12, 115-123.

Dziuk, P.J. (1977) Reproduction in pigs. In Reproduction in Domestic Animals, pp. 456-475. Eds. H. H. Cole \& P. T. Cupps. Academic Press, New York.

Egbunike, G.N. \& Steinbach, J. (1980) Seasonal changes in sow fertility in a humid tropical environment. Zentbl. VetMed. A. 27, 109-117.

Foxcroft, G.R. \& van de Wiel, D.F.M. (1982) Endocrine control of the oestrous cycle. In Control of Pig Reproduction, pp. 161-177. Eds D. J. A. Cole \& G. R. Foxcroft. Butterworths Scientific, London.

Greenberg, L.G. \& Mahone, J.P. (1981) The effect of a 15-h photoperiod on reproductive function in boars at 2, 3, 4 or 5 months of age. Can. J. Anim. Sci. 61, 925-934.

Greenberg, L.G. \& Mahone, J.P. (1982) Failure of a $16 \mathrm{~h}$ $\mathrm{L}: 8 \mathrm{~h} \mathrm{D}$ or an $8 \mathrm{~h} \mathrm{~L}: 16 \mathrm{~h} \mathrm{D}$ photoperiod to influence lactation or reproductive efficiency in sows. $\mathrm{Can} . J$. Anim. Sci. 62, 141-145.

Henze, A. \& Kretzschmar, A. (1980) Zur Organisation der duldungsorienticrten Besamung von Sauen. Tierzuch 34, 35-38.

Hoagland, T.A. \& Diekman, M.A. (1982) Influence of supplemental lighting during increasing daylength on libido and reproductive hormones in prepubertal boars. J. Anim. Sci. 55, 1483-1489.

Hühn, U. \& Henze, A. (1984) MaBnahmen zur Uberwindung saisonaler Fruchtbarkeitsschwankungen beim Schwein als Beitrag zu einer kontinuierlichen Schweineproduktion. Tierzuch 38, 140-142.

Hughes, P.E. (1982) Factors affecting the natural attainment of puberty in the gilt. In Control of Pig Reproduction. pp. 117-138. Eds D. J. A. Cole \& G. R. Foxcroft. Butterworths Scientific, London.

Hurtgen, J.P. \& Leman, A.D. (1978) Seasonal breeding pattern in parous sows: a slaughterhouse survey. Proc. 5th Iht. Pig Vet. Soc., Zagreb, M 50, Abstr.

Hurtgen, J.P. \& Lemon, A.D. (1980) Seasonal influence on the fertility on sows and gilts. J. Am. vet. med. Ass. 177, 631-635.

Hurtgen, J.P. \& Leman, A.D. (1981a) Effect on parity and scason of farrowing on the subsequent farrowing interval of sows. Vet. Rec. 108, 32-34.

Hurtgen, J.P. \& Leman, A.D. (I98Ib) The seasonal breeding pattern of sows in seven confinements herds. Theriogenology 16, 505-511.

Hurtgen, J.P., Leman, A.D. \& Crabo, B. (1980a) Seasonal influence on estrous activity in sows and gilts. J. Am. vet. med. Ass. 176, 119-123.

Hurtgen, J.P., Leman, A.D. \& Crabo, B. (1980b) Effect of season, parity and housing factors on the control of estrus and fertility in swine. Proc. $6 \mathrm{th} \mathrm{Int}$. Pig. Vet. Soc., Copenhagen 20, Abstr.

Jaussiaux, M. (1964) Contribution a l'etude des variations saissonnieres de la fecondite en insemination artificielle porcine. Proc. $5 \mathrm{th} \mathrm{Int}$. Cong. Anim. Reprod. \& A.I.. Trento, 476-480.

Keindorf, A. \& Plescher, W. (1981) Die Jahreszeiteinflūsse auf die Fruchtbarkeit der Schweine unter besonderer Berücksichtigung der Sommermonate. Mh. VelMed. 36, 324-330.

Kopriva, J. \& Pikhard, R. (1981) Schwankungen morphologischer Veränderung der Zuchteberspermien in Abhängigkeit von der Jahreszeit und vom Staliklima. Sb. čsl. Akad. zeméd. Véd E 26, 197-209.

Kovacevic, R., Pujin, D., Gerhard, P., Selak, D., Krsmanovic, L. \& Stojilkovic, S. (1984) Seasonal differences in the renewal of ovarian activity of sows after weaning their litters. Veterinarski Glasnik 38, 25-28.

Krufi, B. \& Brem, G. (1983) Experiences with estrus induction in sows. Proc. $5 \mathrm{~h} \mathrm{~h} \mathrm{~m}$. Conf. on Production Disease in Farm Animals, Uppsala, pp. 248-251.

Lincoln, G.A. \& Short, R.V. (1980) Seasonal breeding: Nàture's contraceptive, Recent Prog. Horm. Res. 36, $1-52$.

Louda, F., Smerha, J. \& Bachtik, M. (1983) Vliv rocniho obdobi na reprodukeni znaky kancu pusobicich $v$ inseminaci. Sb. csl. Akad. Zeméd. Véd E 28, 39-47.

Love, R.J. (1981) Seasonal infertility in pigs. Vet. Rec. 109, 407-409.

Lutter, K. \& Hühn, U. (1980) Untersuchungen über jahreszeitliche Schwankungen der Sauenfruchtbarkeit. Mh. VetMed. 35, 819-822.

Mabry, J.W., Cunningham, F.L., Kraeling, R.R. \& Rampacek, G.B. (1982) The effect of artificially extended photoperiod during lactation on maternal performance of the sow. J. Anim. Sci. 54, 918-921. 
Mabry, J.W., Coffey, M.T. \& Seerley, R.W. (1983) A comparison of an 8-versus 16-hour photoperiod during lactation on suckling frequency of the baby pig and maternal performance of the sow. J. Anim. Sci. 57, 292-295.

Mahone, J.P., Berger, T., Clegg, E.D. \& Singleton, W.L. (1979) Photoinduction of puberty in boars during naturally occurring short day length. J. Anim. Sci. 48, 1159-1164.

Maksimovic, A. (1983) Reproductive performance of gilts mated in different seasons. Vet. Glasn. 37, 297-302.

Martinat-Botte, F., Dando, P., Gautier, J. \& Terqui, M. (1981) Variations saisonnière de la taille de la porté en relation avec cells du taux d'ovulation et de la mortalite embryonaire chez la Truie. Journées Rech. porc. en France 13, 269-275.

Mattioli, M., Taschini, S., Galeati, G. \& Seren, E. (1983) Possibility of assessing the incidence of fetal mortality in sows by early pregnancy diagnosis. Selez. vet. 24, 1333-1337.

Mauget, R. (1982) Seasonality of reproduction in the wild boar. In Control of Pig Reproduction, pp. 509-526. Eds D. J. A. Cole \& G. R. Foxcroft. Butterworth Scientific, London.

Mazzari, G., du Mesnil du Buisson, F. \& Ortavant, R. (1968) Action de la temperature et de la lumiere sur la spermatogenese la production et le pouvoir lecondant du sperme chez le verrat. Proc. $6 \mathrm{~h} / \mathrm{h} \mathrm{h}$. Congr. Anim. Reprod. \& A.I., Paris, Vol. 1, 305-308.

Mezger, K. (1984) Saisonale Schwankungen des Fruchbarkeitsgeschehens bein weiblichen HausschweinUntersuchung anhand von Daten einer Besamungsssation und eines Praxisbetriebes. Diplomarbeit Universität Hohenheim, Fachgebiet Tierhaltung.

Minton, J.E., Fent, R.W. \& Wettemann, R.P. (1980) Influence of photoperiod on reproductive development of boars. J. Anim. Sci. 51, 306, Abstr.

Nauk, V. \& Sekrii, I. (1983) The reproductive cycle in sows. Svinovodstvo 3, 30-31.

Noguera, J.L., Felgines, C. \& Legault, C. (1983) Evolution de 1972 a 1981 de composantes de la productivite numerique des truies dans 325 troupeaux francais. Journées Rech. porc. en France 15, 37-51.

Ortavant, R., Mauleon, P. \& Thibault, C. (1964) Photoperiodic control of gonadal and hypophyseal activity in domestic animals. Ann N.Y, Acad. Sci. 177, 157-193.

Perera. A.N.M. \& Hacker, R.R. (1984) The effect of different photoperiods on reproduction in the sow. $J$. Anim. Sci. 58, 1418-1422.

Perera, A.N.M., Hacker, R.R. \& King, G.J. (1980) Effect of different photoperiods on reproduction in the sow. Proc. 6th Int. pig vet. Soc., Copenhagen, 21.

Perotti, L., Enne, G., Meggiolaro, D. \& Delrio, G. (1979) Progesterone levels in sows during estrus cycle in summer and in winter season. Riv. Zootec. Vet. 1, 10-12.
Peter, W., Frank, C., Mudra, K. \& Ueckert, H. (1981) Der Einfluß der Aulzucht von Jungebern in zentralen Stationen auf Besamungseignung und Spermaproduktionsvermögen. Tierzuch 35, 92-95.

Podzo, M. \& Varadin, M. (1983) Ondos izmedu kvalitete ejakulata nerestova $\mathrm{i}$ broga prasadi $u$ leglu. Veterinaria 32, 19-24.

Schilling, E. (1968) Die Wirkung einer hormonalen Hypophysenblockade auf die Hodenentwicklung beim Hausschwein. Verh. Deutsch. Zool. Anz. Suppl. 31, Abstr.

Schindler, A. (1980) Saisonalität des Fortpflanzungsgeschehens beim Eber? Untersuchungen anhand der Praxisergebnisse einer Besamungsstation. Diplomarbeit TU München, Weihenstephan.

Schopper, D., Gaus, J., Claus, R. \& Bader, H. (1984) Scasonal changes of steroid concentrations of an european wild boar. Acta endocr., Copenh. 107, 425-427.

Signoret, J.-P. (1967) Duree du cycle oestrien et de loestrus chez la truie, action du benzoate d'oestradiol chez la femelle ovariectomisee. Ann/s Biol. anim. Biochim. Biophys. 7, 407-421

Stevenson, J.S., Pollmann, D.S., Davis, D.L. \& Murphy, J.P. (1983) Influence of supplemental light on sow performance during and after lactation. J. Anim. Sci. 56, 1282-1286.

Stork, M.G. (1979) Seasonal reproductive inefficiency in large pig breeding units in Britain. Vet. Rec. 104, 49-52.

te Brake, J.H.A. \& Arts, J.A.M. (1982) Influence of housing, season and management on sow fertility. Bedrigfsonwikkeling 13,716-719.

Tomes, G.J. \& Nielsen, H.E. (1979) Seasonal variations in the reproductive performance of sows under different climatic conditions. World Rev. Anim. Prod. 15, 9-19.

Turek, F.W. \& Campbell, C.S. (1979) Photoperiodic regulation of neuroendocrine-gonadal activity. Biol. Reprod. 20, 32-50.

Wandursky, A. (1982) A trial of hormone treatment to prevent seasonal disturbances of reproduction in pigs. Med. Wet. 38, 74-76.

Willecke, H., Metges, C. \& Oster, A. (1984) Genetische und umweltbedingte Einflūsse auf das Alter beim 1 . Oestrus von Jungsauen der Rasse Pietrain. Zuchthygiene 19, 205-210.

Wise, M., Jones, A., Allrich, R. \& Zimmermann, D.R. (1980) Influence of photoperiod and relocation-boar exposure stimuli on age at puberty in confinementreared gilts. J. Anim. Sci. 51, 88, Abstr.

Wright, I.A., English, P.R. \& Robertson, A.M. (1984) Daylength and reproductive development in gilts. Farm Building Progress 75, 21-23. 